\title{
Mast cell density in isolated monkey lungs on exposure to cigarette smoke
}

\author{
A WALTER, S WALTER \\ From the Departments of Pathology and Physiology, Christian Medical College and Hospital, Vellore, South \\ India
}

ABSTRACT The density and percentage of degranulated cells of the mast cell population were studied in the isolated lungs of 25 monkeys (Macaca radiata radiata) before and after acute exposure to cigarette smoke. In each animal one lung was used as the test lung while the other lung was used as its control. In the control lungs the total mean mast cell count was $9.5 / \mathrm{mm}^{2}$ and the proportion of degranulated cells was $9.7 \%$. In the lungs exposed to smoke the total counts were lower $\left(7 \cdot 3 / \mathrm{mm}^{2}\right)$ and the percentage of degranulated cells higher $(15 \cdot 8 \%)$. These differences were statistically significant $(p<0.01)$ and show that after acute exposure to cigarette smoke there is a degranulation of lung mast cells. Since degranulation is accompanied by local release of histamine, which could act on the smooth muscle of the airways, it is suggested that this may be a mechanism by which smoking-induced acute bronchoconstriction is mediated.

Among the many harmful effects of cigarette smoke on the airways is the development of obstruction to airflow.' Several factors, including altered surface tension forces and inflammatory changes with excessive mucus secretion and oedema, have been thought to play a part in causing this obstruction. ${ }^{2}$ The immediate effect of smoking, however, is a prompt and reversible bronchoconstriction, ${ }^{3}$ suggesting that smooth muscle contraction may also be concerned in the development of obstruction. One of the mechanisms by which smooth muscle contraction is mediated in the lung is through the action of histamine. ${ }^{4}$ Some studies have indicated that histamine may play a part in mediating smokinginduced bronchoconstriction. ${ }^{56}$ The chief reservoir of histamine in the normal human lung is the mast cell ${ }^{4}$ and degranulation of these cells has been shown by many studies to be associated with histamine release. ${ }^{7}$ Hence it is attractive to postulate that smoking-induced degranulation of lung mast cells with local histamine release might be a mechanism by which bronchoconstriction occurs. This study was undertaken to test the hypothesis by enumerating the lung mast cell population before and after acute exposure to cigarette smoke.

Address for reprint requests: Professor A Walter, Department of Pathology, Christian Medical College Hospital, Vellore 632004, Tamil Nadu, South India.

\section{Methods}

Freshly excised monkey lungs were used as the experimental material because they were easily available and their lung structure and airway subdivisions have a general similarity to those of human lungs. ${ }^{8}$ Twenty-five Macaca radiata radiata monkeys (10 females and 15 males) weighing from $1.5 \mathrm{~kg}$ to $4.5 \mathrm{~kg}$ were used. The animals were anaesthetised with intramuscular nembutal, $30 \mathrm{mg} / \mathrm{kg}$ and the lungs with main bronchi and trachea were removed en masse.

One lung from each animal served as the test lung while the other served as its control. The lungs were separated at the carina, gently wiped free of blood, and weighed. They were then cannulated and ventilated independently and simultaneously with Starling respirators at identical rates of $15 / \mathrm{min}$ and similar volumes. The ventilatory volumes used for the lungs from different animals ranged from 50 to 100 $\mathrm{ml}$, depending on the size of the lungs. The control lung was ventilated with humidified air, while the test lung was ventilated with humidified cigarette smoke from two cigarettes, both for 15 minutes. Humidification was achieved by passage through moist chambers connected to the respirators. The smoke and air at the respirator outlet connected to the lung were at room temperature. The test lung was the right lung in 13 animals and the left lung in 12. After ventilation the lungs were immediately inflated and fixed with buffered alcoholic formalin 


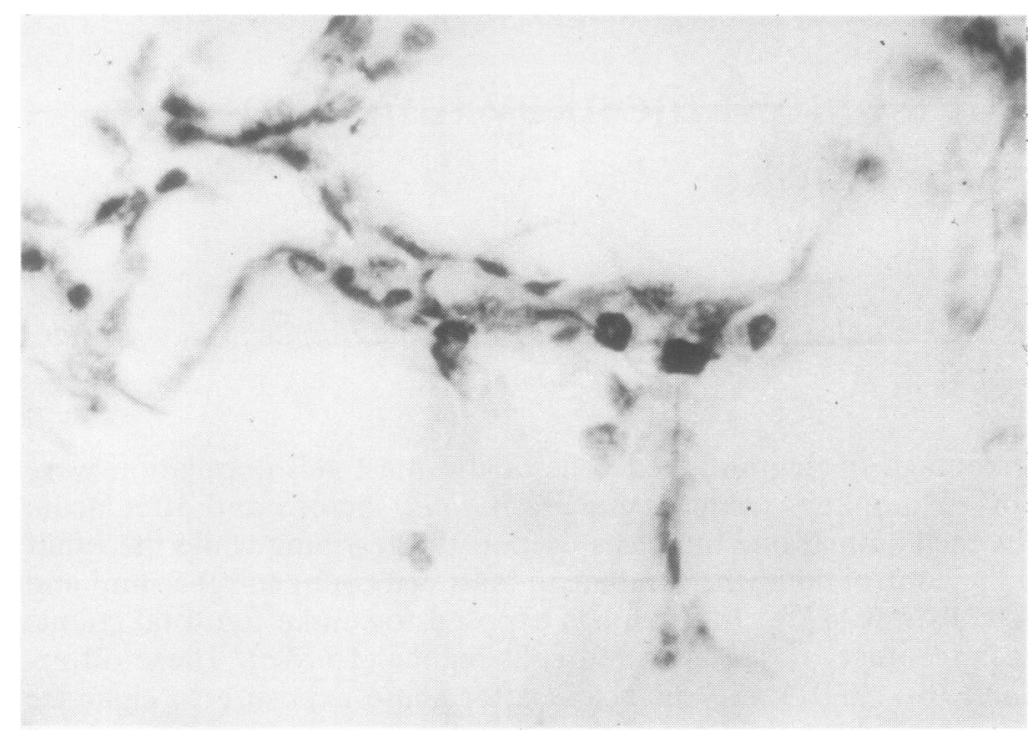

Fig 1 "Intact" mast cells in relation to small pulmonary vessel and alveolar wall (alcoholic thionine, $\times 620$ ).

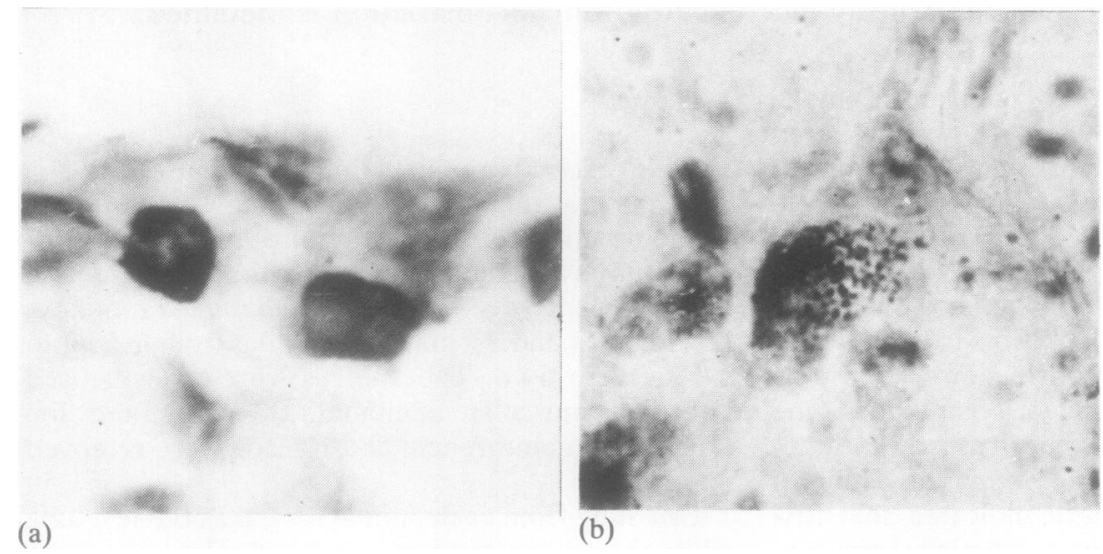

Fig 2 (a) Higher magnification of "intact" mast cells in figure 1; (b) "degranulated" mast cell (alcoholic thionine, $\times 1600$ ).

$\left(\mathrm{pH} \mathrm{6.8-7 \cdot 0)^{9 }}\right.$ at a constant pressure of $30 \mathrm{~cm} \mathrm{H}_{2} \mathrm{O}$ for 24 hours. Since the expansion of the lower lobes was always more nearly optimal than that of the others, representative blocks of tissue from identical areas were taken from the lower lobes and paraffin embedded. Sections of $5 \mu \mathrm{m}$ were stained with $0.5 \%$ thionine in $20 \%$ ethanol, mounted in DPX mountant, and coded.

Enumeration of mast cells was performed with a $\times 10$ eyepiece and $\times 40$ objective lenses. All the mast cells (parenchymal, perivascular, and peribronchial) in a single section were counted and categorised as "intact" and "degranulated" cells (figs 1 and 2). Since mast cells are identified by their metachromatic granules, completely degranulated mast cells cannot be identified. ${ }^{10}$ Partially degranulated cells were categorised as "degranulated" cells. The area in which the count was carried out was measured by tracing the outline of a magnified image of the section on to graph paper and measuring the area of the image, an identically magnified micrometer scale image being used as an index of magnification. The total number of mast cells counted in one section was divided by the area concerned and counts were expressed as cells per $\mathrm{mm}^{2}$. The mast cell counting and categorisation were done without knowledge of the treatment of the lung as the slides were coded. All the counts were done by a single observer. The data were analysed with the paired $t$ test. 


\section{Results}

The weights, total mast cell counts, and percentage of degranulated mast cells of the control lungs and test lungs are shown in the table. Although in all instances the right lungs were heavier than the left, since 12 right and 13 left lungs were exposed to smoke while 12 left and 13 right lungs acted as controls the mean weight of the control lungs was not significantly different from that of those exposed to smoke. In the control lungs the total mean mast cell count was $9.5 / \mathrm{mm}^{2}$ and the proportion of degranulated cells was $9.7 \%$. This degranulation observed in the control lungs could be attributed partly to physiological degranulation and partly to degranulation due to the experimental procedures, as has been reported for blood basophils." The total counts were lower $\left(7 \cdot 3 / \mathrm{mm}^{2}\right)$ and the percentage of degranulated cells higher $(15.8 \%)(p<0.01)$ in the lungs exposed to smoke than in the control lungs.

\section{Discussion}

These results show that after exposure to cigarette smoke there is a degranulation of lung mast cells. Since mast cell degranulation is associated with histamine release ${ }^{7}$ this suggests that cigarette smoke causes bronchoconstriction by histamine release from mast cells. The mast cells in the lungs are distributed in the parenchyma, around the airways, and around the blood vessels. In the airways and parenchyma mast cells are mostly subepithelial. ${ }^{810}$ Evidence that cigarette smoke could reach the subepithelial location of mast cells comes from the study of Simani et al, ${ }^{12}$ who showed that in guineapigs the respiratory epithelium at all levels becomes more permeable after exposure to cigarette smoke, owing to separation of cell junctions. Once some histamine has been released because of degranulation of mucosal mast cells, it could further alter the integrity of the mucosal barrier ${ }^{4}$ and permit the

Mast cell density and percentage degranulation in isolated monkey lungs exposed to cigarette smoke and control lungs $(n=25)$

\begin{tabular}{|c|c|c|c|c|}
\hline \multirow{3}{*}{$\begin{array}{l} \\
\text { Lung weight }(\mathrm{g}) \\
\text { Total mast cell count } \\
\left(\text { cells } / \mathrm{mm}^{2}\right) \\
\% \text { of degranulated cells }\end{array}$} & \multirow{2}{*}{$\begin{array}{l}\begin{array}{l}\text { Control } \\
\text { Mean }( \pm I S D)\end{array} \\
7 \cdot 4 \pm 4 \cdot 54\end{array}$} & \multirow{2}{*}{$\begin{array}{l}\begin{array}{l}\text { Exposed to } \\
\text { smoke } \\
\text { Mean }( \pm 1 S D)\end{array} \\
6.9 \pm 2.49\end{array}$} & $\begin{array}{l}\text { Differen } \\
S E M\end{array}$ & \multirow{2}{*}{$\begin{array}{c}p^{*} \\
\text { NS }\end{array}$} \\
\hline & & & 0.615 & \\
\hline & $\begin{array}{l}9 \cdot 5 \pm 5 \cdot 57 \\
9 \cdot 7 \pm 4 \cdot 67\end{array}$ & $\begin{array}{r}7 \cdot 3 \pm 4.09 \\
15 \cdot 8 \pm 11.53\end{array}$ & $\begin{array}{l}0.599 \\
2 \cdot 058\end{array}$ & $\begin{array}{l}<0.01 \\
<0.01\end{array}$ \\
\hline
\end{tabular}

*Paired $t$ test used. smoke particles to reach and activate the more deeply placed mast cells.

Histamine has been shown to have a range of varied actions on the mammalian lung. Intravenous histamine produces increased pulmonary resistance and decreased compliance in the unanaesthetised guinea-pig, medicated dog, and resting human subjects, by direct and reflex mechanisms acting on smooth muscle. ${ }^{4}$ It also contributes to acute and subacute inflammatory changes such as increased vascularity, increased mucosal and capillary permeability with cellular infiltration, and increased bronchial glandular secretions. ${ }^{13}$ Many of these effects have also been reported to occur after shortterm or long-term exposure to cigarette smoke. ${ }^{14}$

Thus mast cell activation with histamine release might be an important mechanism whereby the immediate and possibly also the chronic effects of smoking on the airways are mediated. Guerzon et al $^{8}$ have reported that in the lungs of the monkey Macaca fasicularis $17 \%$ of the total mast cell population is located in the parenchyma and $83 \%$ in the conducting airways, their number increasing from the central to the peripheral airways. On the assumption that the distribution of mast cells in human airways is similar, this might explain why the peripheral airways show earlier and more serious effects of smoking than the central airways.

The effect of hypoxia on mast cells is also relevant to the present findings. It has been shown that there is periarterial mast cell degranulation with release of histamine in acute alveolar hypoxia, ${ }^{15}$ while mast cell hyperplasia has been shown in chronic hypoxia in animals ${ }^{1617}$ and in human fibrotic lung disorders. ${ }^{18}$ In smokers with peripheral airway narrowing, impairment of gas exchange and hypoxaemia due to ventilation-perfusion imbalance may be present. ${ }^{19}$ In fact, hypoxaemia has been found even in young symptomless smokers. ${ }^{20}$ Thus one of the long-term effects of smoking could be an increase in mast cell density and therefore potential for histamine release in the lung.

This study was supported by a grant from the Indian Council of Medical Research, New Delhi.

\section{Addendum}

Since this paper was accepted, our attention has been drawn to a paper by Neurman et al (Respir Physiol 1980;40:191-8) on the distribution of mast cells.

\section{References}

${ }^{1}$ US Department of Health, Education, and Welfare. Smoking and chronic bronchopulmonary diseases 
(non-neoplastic). The health consequences of smoking: a public health service review. Part II. Washington DC: US Public Health Service, 1967: ch 2.

${ }^{2}$ Ebert RV, Terracio MJ. The bronchiolar epithelium in cigarette smokers: observations with the scanning electron microscope. Am Rev Respir Dis 1975;111:4-11.

${ }^{3}$ Nadel JA, Comroe JH jun. Acute effects of inhalation of cigarette smoke on airway conductance. $J$ Appl Physiol 1961;16:713-6.

${ }^{4}$ Lewis RA, Austen KF. Non-respiratory functions of pulmonary cells: the mast cell. Fed Proc 1977;36:2676-83.

5 Aviado DM, Samanek M, Folle LE. Cardiopulmonary effects of tobacco and related substances. Arch Environ Health 1966;12:705-11.

- Walter S, Nancy NR. Basopenia following cigarette smoking. Indian J Med Res 1980:72:422-5.

${ }^{7}$ Uvnas B. The mechanism of histamine liberation. $J$ Pharm Pharmacol 1958;10:1-13.

${ }^{8}$ Guerzon GM, Pare PD, Michond MC, Hogg JC. The number and distribution of mast cells in monkey lungs. Am Rev Respir Dis 1979;119:59-66.

${ }^{9}$ Lillie RD, Fullmer HM. Histopathologic technic and practical histochemistry. 4th ed. New York: McGraw-Hill Book Company, 1976:674.

${ }^{10}$ Connell JT. Asthmatic deaths: role of the mast cells. JAMA 1971;215:769-76.

"Dvorak AM, Newball HH, Dvorak HF, Lichtenstein LM. Antigen induced IgE-mediated degranulation of human basophils. Lab Invest 1980;43:126-39.

12 Simani IAS, Inoue S, Hogg JC. Penetration of the respiratory epithelium of guinea pigs following exposure to cigarette smoke. Lab Invest 1974;31:75-87.

${ }^{13}$ Brocklehurst WE. The pharmacology of asthma and possible therapeutic developments. In: Porter R, Birch J, eds. Ciba Foundation Symposium on Identification of Asthma. London: Churchill Livingstone, 1971:132-42.

${ }^{14}$ Larson PS, Silvette H. Tobacco. Experimental and clinical studies. A comprehensive account of the world literature. Supplement 1. Baltimore: Williams and Wilkins Co, 1968:138-51.

${ }^{15}$ Bergofsky $\mathrm{EH}$, Mechanisms underlying vasomotor regulation of regional pulmonary blood flow in normal and disease states. Am J Med 1974;57:378-94.

${ }^{16}$ Kay JM, Waymire JC, Grover RF. Lung mast cell hyperplasia and pulmonary histamine-forming capacity in hypoxic rats. Am J Physiol 1974;226:178-84.

${ }^{17}$ Mungall IPF. Hypoxia and lung mast cells: influence of $\vec{\oplus}$ disodium chromoglycate. Thorax 1976;31:94-100.

${ }^{18}$ Kawanami O, Ferrans VJ, Fulmer JD, Crystal RG. Ultrastructure of pulmonary mast cells in patients with fibrotic lung disorders. Lab Invest 1979;40:717-34.

${ }^{19}$ Anthonisen NR, Bass H, Oriol A, Place REG, Bates DV. Regional lung function in patients with chronic bronchitis. Clin Sci 1968;35:495-511.

${ }^{20}$ Streider DJ, Kazemi H. Hypoxemia in young asymptomatic cigarette smokers. Ann Thorac Surg 1967;4:523-31. 